\title{
ROLE OF MOMETASONE FUROATE NASAL SPRAY IN ADENOID HYPERTROPHY IN CHILDREN WITH OSA
}

\author{
Praveen Prasannan ${ }^{1}$, Sadarudheen Ahmed Mohammed Islah ${ }^{2}$
}

1 Junior Resident, Department of ENT, Government Medical College, Kottayam.

${ }^{2}$ Additional Professor, Department of ENT, Government Medical College, Alappuzha.

ABSTRACT
BACKGROUND
Adenoid hypertrophy is one of the main causes of upper airway obstruction and Obstructive Sleep Apnoea (OSA) in children.
Studies have shown that administration of mometasone furoate aqueous nasal spray significantly improved oxygen saturation in
children with sleep-disordered breathing.
The aim of this study is to evaluate the effect of mometasone furoate aqueous nasal spray on oxygen saturation measured
through nocturnal pulse oximetry and quality of life in children with sleep-disordered breathing due to adenoid hypertrophy.

\section{MATERIALS AND METHODS}

Eighty children suspected of having sleep-disordered breathing due to adenoid hypertrophy, whose parents were not willing for surgery (Adenoidectomy) were enrolled in a non-controlled clinical trial. Quality of life questionnaire was distributed pre- and post-interventional and the symptoms were scored depending on its frequency of occurrence. Pre- and post-intervention x-ray nasopharynx taken. Pre- and post-intervention nocturnal oxygen saturation monitoring was done and Oxygen Desaturation Index (ODI) as well as desaturation events were recorded. Data was analysed using paired student t-test and Wilcoxon's Signed Rank Tests.

\section{RESULTS}

Out of the 80 study population, 43 were males (53.8\%) and 37 were females (46.2\%). Age distribution of the population ranged from 3 to 10 years with a mean age of 6.2 years. The study showed a strong positive correlation between grade of adenoid size and ODI ( $\mathrm{r}-0.790 ; \mathrm{p}<0.001)$. All the pulse oximetric parameters improved significantly after drug administration $(\mathrm{p}<0.001)$. There was a significant improvement in the quality of life of these children after the treatment.

\section{CONCLUSION}

The study revealed mometasone furoate aqueous nasal spray therapy leads to significant reduction in adenoid size and gives symptomatic relief for children with sleep disordered breathing. It can be recommended as the prime medical treatment modality for children with sleep disordered breathing, as it substantially reduced the morbidity and health care utilisation by these children.

\section{KEYWORDS}

Sleep-disordered Breathing, Obstructive Sleep Apnoea, Adenoid Hypertrophy, Mometasone Furoate, Oximetry.

HOW TO CITE THIS ARTICLE: Prasannan P, Islah SAM. Role of mometasone furoate nasal spray in adenoid hypertrophy in children with OSA. J. Evolution Med. Dent. Sci. 2016;5(93):6891-6896, DOI: 10. 14260/jemds/2016/1558

\section{BACKGROUND}

The adenoids (Pharyngeal or Luschka's tonsil) are a single, pyramid-shaped aggregation of lymphoid tissue with the apex pointed toward the nasal septum and the base at the level of the roof and posterior wall of the nasopharynx. Present at birth, this lymphoid structure undergoes hypertrophy until 7 years of age, usually reaching a maximal size around the age of 4 years; later, it begins to atrophy until it almost invariably disappears in adulthood. The nasopharyngeal tonsil is a part of Waldeyer's ring, situated at the entrance of the aerodigestive tract and composed of the adenoid pad in addition to the palatine, tubal and lingual tonsils.

Financial or Other, Competing Interest: None.

Submission 18-10-2016, Peer Review 12-11-2016,

Acceptance 17-11-2016, Published 21-11-2016.

Corresponding Author:

Dr. Sadarudheen Ahmed Mohammed Islah,

Additional Professor,

Department of ENT,

Government Medical College,

Vandanam P. O, Alappuzha.

E-mail: drsadarudeen@yahoo.com

DOI: 10. 14260/jemds/2016/1558
Adenoid Hypertrophy (AH), a common disorder in the paediatric population presents with several symptoms, ranging from nasal obstruction to Obstructive Sleep Apnoea Syndrome (OSAS). Adenoidectomy is currently considered the treatment of choice for children with severe symptoms caused by $\mathrm{AH}$, although more conservative treatments using topical, intranasally administered, steroid preparations have been reported. AH is probably the most frequent pathologic condition occurring in the paediatric age group. It leads to different clinical manifestations according to adenoid size. Bilateral nasal obstruction is a primary complaint that can be associated with different sleep disorders, ranging from snoring to OSAS. ${ }^{1}$ Rhinorrhoea, mouth-breathing, hyponasal speech and cough can also be observed in patients with $\mathrm{AH}$. In addition, $\mathrm{AH}$ seems to favour the occurrence of recurrent and effusive otitis media and recurrent and chronic rhinosinusitis.

Finger palpation, ${ }^{2}$ transoral mirror adenoid examination and baseline lateral soft-tissue radiographs ${ }^{3}$ of the nasopharynx commonly have been used to assess adenoid size. At present, $\mathrm{AH}$ is one of the most frequent indications for surgery in childhood and adenoidectomy commonly is 
considered definitive treatment for nasopharyngeal obstruction.

Nevertheless, this surgical technique has been the subject of some criticism that the removal of adenoid lymphatic tissue could have a negative impact on the systemic immunologic system. 4,5 Moreover, immediate postintervention or late bleeding is observed in $1 \%$ of children who undergo adenoidectomy. Furthermore, it is well demonstrated that adenoids may recur after surgery in $10 \%$ to $20 \%$ of cases.

In the past decade, several authors have proposed the use of topical nasal steroids to decrease $\mathrm{AH}$ with the intent to preserve immunologically active tissue and to avoid the anaesthesiologic and surgical risks inherent in adenoidectomy.

\section{MATERIALS AND METHODS}

80 children with symptoms suggestive of OSAS due to AH and whose parents were not willing for surgery were selected for study. At enrolment, patients needed to meet the following inclusion criteria: (1) Adenoid hypertrophy diagnosed by $\mathrm{x}$ ray nasopharynx lateral view, (2) Age between 3 and 10 years, (3) Symptoms consistent with OSAS lasting $\geq 6$ months and (4) No previous adenoidectomy. Children with concomitant tonsillar hypertrophy, positive history of allergy or atopy, upper respiratory infection within the past 2 weeks, nasal anatomic anomalies (eg, nasal septum deviation) or sinonasal diseases such as hypertrophy of inferior turbinates and/or nasal polyposis, craniofacial malformations including labiopalatal clefts, genetic diseases (eg, Down syndrome), neurologic disorders, cardiovascular diseases, immunodeficiency, history of epistaxis, hypersensitivity to steroids or intranasal, topical or systemic steroid or antibiotic treatment within the past 4 weeks were excluded.

Dosage-metered dose of 50 microgram (Manual pump spray) of mometasone furoate aqueous nasal spray on both nasal cavity once daily for a period of three months.

Quality of life questionnaire was distributed pre- and post-intervention and the symptoms were scored depending on its frequency of occurrence. The questionnaire encompasses most of the symptoms of Sleep Disordered Breathing (SDB) and $\mathrm{AH}$, which was scored from 0 to 5 depending on its frequency of occurrence. The children who were selected for the study were programmed for evaluating pulse oximetry 1 - 2 days before and 3 months after the therapy ${ }^{6}$ by keeping the child in observation room. The duration of overnight pulse oxymetry 7,8 is 8 hours (from 10 PM to 6 AM). EmcoRoxi-sat 2060 pulse oximeter, which has a memory of up to 72 hours was used for this study. The following variables were studied:

- Oxygen Desaturation Index (ODI),

- Mean saturation, and

- Minimum saturation.

ODI is defined as the total number of desaturation events divided by the total duration of sleep in hours. A desaturation event was considered when the haemoglobin saturation level (Sp02) fell below 4\% from baseline saturation. Baseline saturation was considered as the mean saturation in the previous minute. Falls in oxygen saturation to $>4 \%$ in the interval $90-100 \%$ of saturation were also considered as desaturations. ODI was obtained for each patient with three cut-off points: > 5 (ODI - 5), > 10 (ODI - 10) and > 15 (ODI $15)$.

The oximetric data collected were analysed and all desaturation of $>4 \%$ were identified and noted. Validity of the test was approved if the duration of oximetric monitoring was 6 hours or more and if oxygen saturation data was reliable and compatible with pulse rate according to the pulse rate variable recorded in the memory of pulse oximeter. Same repeated after completion of treatment.

Pre- and post-intervention oximetric variables were analysed using paired student t-test or Wilcoxon test depending on the variables. Correlation between variables was considered using Pearson correlation test. The data were analysed statistically with SPSS version 16 packages for windows.

\section{RESULTS}

\section{Observations}

80 children in the age group 3 - 10 years who attended the OPD of the Department of ENT, Medical College, Kottayam, with clinical features suggestive of chronic adenoid hypertrophy and symptoms suggestive of OSAS were selected for the study. The study was conducted for a period of 18 months from January 2012 to May 2013. The following observations were made.

\section{Sex Distribution}

\begin{tabular}{|c|c|c|}
\hline & Number & Percentage \\
\hline Male & 43 & 53.8 \\
\hline Female & 37 & 46.2 \\
\hline Total & $\mathbf{8 0}$ & $\mathbf{1 0 0 . 0}$ \\
\hline \multicolumn{2}{|c|}{ Table 1. Sex Distribution of Study Population } \\
\hline
\end{tabular}

Out of the 80 study population, 43 were males (53.8\%) and 37 were females (46.2\%). Male-to-female proportion is given below:

\section{Adenoid Hypertrophy}

Adenoids were graded radiologically as a continuous variable from I to IV. The frequency and percent distribution are as given below:-

\section{Adenoid Grade}

\begin{tabular}{|c|c|c|}
\hline & Frequency & Percentage \\
\hline 1 & 0 & 0 \\
\hline 2 & 7 & 8.8 \\
\hline 3 & 43 & 53.8 \\
\hline 4 & 30 & 37.5 \\
\hline Total & $\mathbf{8 0}$ & $\mathbf{1 0 0 . 0}$ \\
\hline \multicolumn{2}{|c|}{ Table 2. Grades of Adenoid Hypertrophy } \\
among Study Population \\
\hline
\end{tabular}

Majority of study population (53.8\%) had Grade III adenoids (Enlarged adenoids filling from $2 / 3$ rd of vertical portion of choanae to nearly complete obstruction). 
Comparing Pre- and Post-Intervention Pulse Oximetric Parameters among Study Population Oxygen Desaturation Index

\begin{tabular}{|c|c|c|c|c|}
\hline \multirow{2}{*}{$\begin{array}{c}\text { OD } \\
\text { Episodes }\end{array}$} & Frequency & Percentage & Frequency & Percentage \\
\cline { 2 - 5 } & 4 & 5.0 & 64 & 80 \\
\hline$<5$ & 21 & 26.2 & 16 & 20 \\
\hline $5-10$ & 40 & 50.0 & 0 & 0 \\
\hline $10-15$ & 15 & 18.8 & 0 & 0 \\
\hline$>15$ & $\mathbf{8 0}$ & $\mathbf{1 0 0 . 0}$ & $\mathbf{8 0}$ & $\mathbf{1 0 0}$ \\
\hline \multicolumn{2}{|c|}{ Table 3. Pre-Intervention and Post-Intervention ODI Grades } \\
\hline
\end{tabular}

Above is the comparison of pre-intervention and postintervention oxygen desaturation episodes.

During pre-intervention most of the patients had ODI grade $10-15$, while post-intervention majority have ODI grade $<5$.

\section{Mean SP02}

\begin{tabular}{|c|c|c|c|c|c|}
\hline Mean SP02 & Mean & N & Sd & t & p \\
\hline $\begin{array}{c}\text { Pre- } \\
\text { Intervention }\end{array}$ & 91.081 & 80 & 1.9084 & -30.098 & $<0.001$ \\
\hline $\begin{array}{c}\text { Post- } \\
\text { Intervention }\end{array}$ & 94.930 & 80 & 1.3631 & & $<0.001$ \\
\hline \multicolumn{7}{|c|}{ Table 4. Comparing Pre-Intervention and Post- } \\
Intervention Mean SPO2
\end{tabular}

Paired ' $\mathrm{t}$ ' test was used. Average mean SPO2 preintervention was 91.081, SD 1.9084 and that postintervention was 94.930, SD 1.331. P value was $<0.001$.

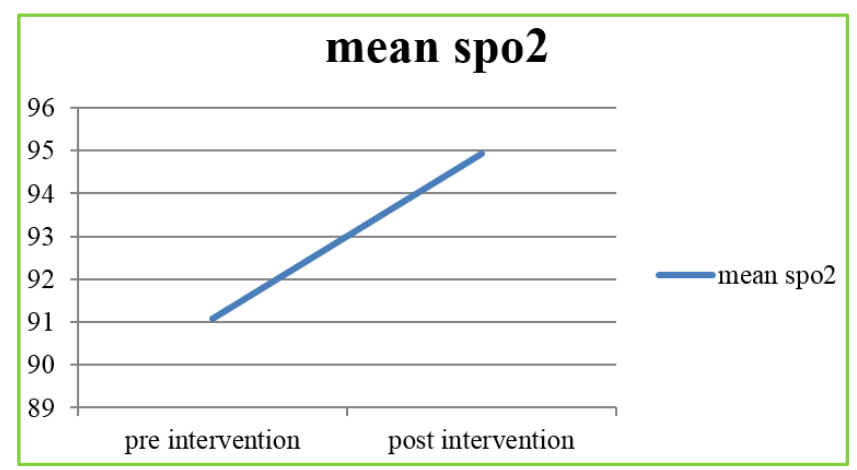

Figure 1. Comparing Pre-Intervention and Post-Intervention Mean SPO2

Minimum SPO2

\begin{tabular}{|c|c|c|c|c|c|}
\hline $\begin{array}{c}\text { Minimum } \\
\text { SP02 }\end{array}$ & Mean & N & Sd & t & p \\
\hline $\begin{array}{c}\text { Pre- } \\
\text { Intervention }\end{array}$ & 80.56 & 80 & 2.666 & -29.255 & $<0.001$ \\
\hline $\begin{array}{c}\text { Post- } \\
\text { Intervention }\end{array}$ & 87.06 & 80 & 2.492 & & $<0.001$ \\
\hline \multicolumn{4}{|c|}{$\begin{array}{c}\text { Table 5. Comparing Pre-Intervention } \\
\text { and Post-Intervention Minimum SPO2 }\end{array}$} \\
\hline
\end{tabular}

Paired ' $\mathrm{t}$ ' test was used. Average minimum Sp02 preintervention was 80.56, SD 2.666 and that post-intervention was 84.11 , SD 2.492 and $p$ value was $<0.001$.
Evaluating the Quality of Life Pre- and PostInterventional among Study Population

Non-parametric Wilcoxon's Signed Rank Test was used for evaluating the continuous scores of quality of life questionnaire. The following observations were made:-

Nasal Obstruction

\begin{tabular}{|c|c|c|c|c|c|}
\hline $\begin{array}{c}\text { Nasal } \\
\text { Obstruction }\end{array}$ & \multicolumn{2}{|c|}{$\begin{array}{c}\text { Pre- } \\
\text { Intervention }\end{array}$} & \multicolumn{2}{|c|}{$\begin{array}{c}\text { Post- } \\
\text { Intervention }\end{array}$} & $\begin{array}{l}\text { Wilcoxon's } \\
\text { Signed }\end{array}$ \\
\hline Never & 0 & 0 & 6 & 7.5 & \multirow{7}{*}{$<0.001$} \\
\hline $\begin{array}{c}\text { Almost } \\
\text { never }\end{array}$ & 0 & 0 & 33 & 41.2 & \\
\hline Sometimes & 6 & 7.5 & 39 & 48.8 & \\
\hline Often & 32 & 40 & 2 & 2.5 & \\
\hline Very often & 31 & 38.8 & 0 & 0 & \\
\hline $\begin{array}{l}\text { Could not be } \\
\text { worse }\end{array}$ & 11 & 13.8 & 0 & 0 & \\
\hline Total & 80 & 100 & 80 & & \\
\hline
\end{tabular}

(0, Never; 1, Almost Never; 2, Sometimes; 3, Often; 4, Very Often; 5 , Could not be worse).

Pre-interventional most of the patients (40\%) had nasal obstruction often and post-interventional majority (39) had nasal obstruction sometimes. The p-value was $<0.001$.

\section{Dry Mouth}

\begin{tabular}{|c|c|c|c|c|c|}
\hline \multirow{2}{*}{$\begin{array}{c}\text { Dry Mouth } \\
\text { Never }\end{array}$} & \multicolumn{2}{|c|}{$\begin{array}{c}\text { Pre- } \\
\text { Intervention }\end{array}$} & \multicolumn{2}{|c|}{$\begin{array}{c}\text { Post- } \\
\text { Intervention }\end{array}$} & \multirow[t]{2}{*}{$\begin{array}{l}\text { Wilcoxon's } \\
\text { Signed } \\
\text { Rank Test }\end{array}$} \\
\hline & 5 & 6.2 & 50 & 62.5 & \\
\hline $\begin{array}{l}\text { Almost } \\
\text { Never }\end{array}$ & 28 & 35 & 30 & 37.5 & \multirow{6}{*}{$<0.001$} \\
\hline Sometimes & 35 & 43.8 & 0 & 0 & \\
\hline Often & 12 & 15 & 0 & 0 & \\
\hline Very Often & 0 & 0 & 0 & 0 & \\
\hline $\begin{array}{l}\text { Could Not } \\
\text { Be Worse }\end{array}$ & 0 & 0 & 0 & 0 & \\
\hline Total & 80 & 100 & 80 & & \\
\hline \multicolumn{6}{|c|}{$\begin{array}{c}\text { Table 7. Pre-Intervention and Post-Intervention Dry Mouth } \\
\text { among Study Population }\end{array}$} \\
\hline
\end{tabular}


Snoring

\begin{tabular}{|c|c|c|c|c|c|}
\hline \multirow{2}{*}{$\begin{array}{c}\text { Snoring } \\
\text { Never }\end{array}$} & \multicolumn{2}{|c|}{$\begin{array}{c}\text { Pre- } \\
\text { Intervention }\end{array}$} & \multicolumn{2}{|c|}{$\begin{array}{c}\text { Post- } \\
\text { Intervention }\end{array}$} & $\begin{array}{c}\text { Wilcoxon's } \\
\text { Signed } \\
\text { Rank Test }\end{array}$ \\
\hline & 0 & 0 & 40 & 50 & \multirow{7}{*}{$<0.001$} \\
\hline $\begin{array}{c}\text { Almost } \\
\text { Never }\end{array}$ & 0 & 0 & 34 & 42.5 & \\
\hline Sometimes & 0 & 0 & 6 & 7.5 & \\
\hline Often & 7 & 8.8 & 0 & 0 & \\
\hline Very Often & 55 & 68.8 & 0 & 0 & \\
\hline $\begin{array}{l}\text { Could Not } \\
\text { Be Worse }\end{array}$ & 18 & 22.5 & 0 & 0 & \\
\hline Total & 80 & 100 & 80 & & \\
\hline Tab & $\begin{array}{l}\text { Pre- } \\
\text { cori }\end{array}$ & ve & an & -In & ntion \\
\hline
\end{tabular}

(0, Never; 1, Almost Never; 2, Sometimes; 3, Often; 4, Very Often; 5 , Could not be worse)

Pre-interventional most of the patients (64\%) had snoring very often and post-interventional majority (50.7\%) had snoring sometimes. The p-value was $<0.001$.

\section{Mouth Breathing}

\begin{tabular}{|c|c|c|c|c|c|}
\hline \multirow{2}{*}{$\begin{array}{c}\begin{array}{c}\text { Mouth } \\
\text { Breathing }\end{array} \\
\text { Never }\end{array}$} & \multicolumn{2}{|c|}{$\begin{array}{l}\text { Pre- } \\
\text { Intervention }\end{array}$} & \multicolumn{2}{|c|}{$\begin{array}{l}\text { Post- } \\
\text { Intervention }\end{array}$} & $\begin{array}{c}\text { Wilcoxon's } \\
\text { Signed } \\
\text { Rank Test }\end{array}$ \\
\hline & 0 & 0 & 38 & 47.5 & \multirow{7}{*}{$<0.001$} \\
\hline $\begin{array}{l}\text { Almost } \\
\text { never }\end{array}$ & 0 & 0 & 41 & 51.2 & \\
\hline Sometimes & 0 & 0 & 1 & 1.2 & \\
\hline Often & 12 & 15 & 0 & 0 & \\
\hline Very often & 47 & 58.8 & 0 & 0 & \\
\hline $\begin{array}{l}\text { Could not } \\
\text { be worse }\end{array}$ & 21 & 26.2 & 0 & 0 & \\
\hline Total & 80 & 100 & 80 & & \\
\hline \multicolumn{6}{|c|}{$\begin{array}{l}\text { Table 9. Pre-Intervention and Post-Intervention Mouth } \\
\text { Breathing among Study Population }\end{array}$} \\
\hline
\end{tabular}

(0, Never; 1, Almost Never; 2, Sometimes; 3, Often; 4, Very Often; 5 , Could not be worse)

Pre-interventional most of the patients $(64 \%)$ had mouth breathing very often and post-interventional majority (54.7\%) had mouth breathing sometimes. The p-value was < 0.001 .

\section{Restlessness at Nights}

\begin{tabular}{|c|c|c|c|c|c|}
\hline \multirow{2}{*}{$\begin{array}{c}\text { Restlessness } \\
\text { at Nights }\end{array}$} & \multicolumn{2}{|c|}{$\begin{array}{c}\text { Pre- } \\
\text { Intervention }\end{array}$} & \multicolumn{2}{|c|}{$\begin{array}{c}\text { Post- } \\
\text { Intervention }\end{array}$} & $\begin{array}{c}\text { Wilcoxon's } \\
\text { Signed } \\
\text { Rank Test } \\
\end{array}$ \\
\hline & 0 & 0 & 48 & 60 & \multirow{7}{*}{$<0.001$} \\
\hline Almost Never & 20 & 25 & 30 & 37.5 & \\
\hline Sometimes & 33 & 41.2 & 2 & 2.5 & \\
\hline Often & 25 & 31.2 & 0 & 0 & \\
\hline Very Often & 2 & 2.5 & 0 & 0 & \\
\hline $\begin{array}{c}\text { Could Not Be } \\
\text { Worse }\end{array}$ & 0 & 0 & 0 & 0 & \\
\hline Total & 80 & 100 & 80 & & \\
\hline $\begin{array}{l}\text { Table } \\
\text { Restle }\end{array}$ & 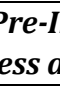 & 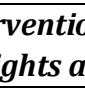 & OI & 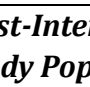 & $\begin{array}{l}\text { tion } \\
\text { tion }\end{array}$ \\
\hline
\end{tabular}

(0, Never; 1 , Almost Never; 2, Sometimes; 3, Often; 4, Very Often; 5, Could not be worse)

Pre-interventional most of the patients (58.7\%) often had restlessness at nights and post-interventional majority (80\%) almost never had restlessness at nights. The p value was < 0.001 .

\section{Choking Episodes}

\begin{tabular}{|c|c|c|c|c|c|}
\hline \multirow{2}{*}{$\begin{array}{c}\text { Choking } \\
\text { Episodes }\end{array}$} & \multicolumn{2}{|c|}{$\begin{array}{c}\text { Pre- } \\
\text { Intervention }\end{array}$} & \multicolumn{2}{|c|}{$\begin{array}{c}\text { Post- } \\
\text { Intervention }\end{array}$} & \multirow[t]{2}{*}{$\begin{array}{l}\text { Wilcoxon's } \\
\text { Signed } \\
\text { Rank Test }\end{array}$} \\
\hline & 4 & 5 & 59 & 73.8 & \\
\hline $\begin{array}{c}\text { Almost } \\
\text { Never }\end{array}$ & 49 & 61.3 & 21 & 26.2 & \multirow{6}{*}{$<0.001$} \\
\hline Sometimes & 27 & 33.8 & 0 & 0 & \\
\hline Often & 0 & 0 & 0 & 0 & \\
\hline Very Often & 0 & 0 & 0 & 0 & \\
\hline $\begin{array}{l}\text { Could Not } \\
\text { Be Worse }\end{array}$ & 0 & 0 & 0 & 0 & \\
\hline Total & 80 & 100 & 80 & & \\
\hline Table 11. & Inte & tion & POS & $\begin{array}{l}\text { terv } \\
\text { ulat }\end{array}$ & n Choking \\
\hline
\end{tabular}

(0, Never; 1, Almost Never; 2, Sometimes; 3, Often; 4, Very Often; 5 , Could not be worse)

\section{Day Time Somnolence}

\begin{tabular}{|c|c|c|c|c|c|}
\hline \multirow{2}{*}{$\begin{array}{c}\begin{array}{c}\text { Day Time } \\
\text { Somnolence }\end{array} \\
\text { Never }\end{array}$} & \multicolumn{2}{|c|}{$\begin{array}{c}\text { Pre- } \\
\text { Intervention }\end{array}$} & \multicolumn{2}{|c|}{$\begin{array}{c}\text { Post- } \\
\text { Intervention }\end{array}$} & \multirow[t]{2}{*}{$\begin{array}{c}\text { Wilcoxon's } \\
\text { Signed } \\
\text { Rank Test }\end{array}$} \\
\hline & 0 & 0 & 52 & 65 & \\
\hline $\begin{array}{l}\text { Almost } \\
\text { Never }\end{array}$ & 7 & 8.8 & 28 & 35 & \multirow{6}{*}{$<0.001$} \\
\hline Sometimes & 44 & 55 & 0 & 0 & \\
\hline Often & 28 & 35 & 0 & 0 & \\
\hline Very Often & 1 & 1.2 & 0 & 0 & \\
\hline $\begin{array}{c}\text { Could Not Be } \\
\text { Worse }\end{array}$ & 0 & 0 & 0 & 0 & \\
\hline Total & 80 & 100 & 80 & & \\
\hline $\begin{array}{c}\text { Table } 1 \\
\text { Day } T\end{array}$ & re- & vent & an & In & $\begin{array}{l}\text { ention } \\
\text { ation }\end{array}$ \\
\hline
\end{tabular}

(0, Never; 1, Almost Never; 2, Sometimes; 3, Often; 4, Very Often; 5 , Could not be worse)

\section{DISCUSSION}

$\mathrm{AH}$ is probably the most frequent pathologic condition occurring in the paediatric age group. It leads to different clinical manifestations according to adenoid size. Bilateral nasal obstruction is a primary complaint that can be associated with different sleep disorders, ${ }^{9}$ ranging from snoring to OSAS. In such a situation which is often observed when palatine tonsillar hypertrophy is also present, patients typically complain of both nighttime and daytime behavioural illnesses (i.e. intermittent sleep, sleepwalking, morning headaches, difficulty concentrating, sleepiness, enuresis, slow feeding and poor growth), which may lead to cardiorespiratory syndromes such as cor pulmonale ${ }^{10}$ in extreme cases. 
Rhinorrhoea, mouth breathing, hyponasal speech and cough can also be observed in patients with AH. In addition, $\mathrm{AH}$ seems to favour the occurrence of recurrent and effusive otitis media and recurrent and chronic rhinosinusitis.

Finger palpation, transoral mirror adenoid examination and baseline lateral soft-tissue radiographs of the nasopharynx commonly have been used to assess adenoid size. At present, $\mathrm{AH}$ is one of the most frequent indications for surgery in childhood and adenoidectomy commonly is considered definitive treatment for nasopharyngeal obstruction. Nevertheless, this surgical technique has been the subject of some criticism. Paulussen et al hypothesised that the removal of adenoid lymphatic tissue could have a negative impact on the systemic immunologic system. Moreover, immediate post-intervention or late bleeding is observed in $1 \%$ of children who undergo adenoidectomy. Furthermore, it is well demonstrated that adenoids may recur after surgery in $10 \%$ to $20 \%$ of cases.

In the past decade, several authors have proposed the use of topical nasal steroids to decrease $\mathrm{AH}$ with the intent to preserve immunologically active tissue and to avoid the anaesthesiologic and surgical risks inherent in adenoidectomy. In 1995, Demain and Goetz described an adenoid reduction using an aqueous nasal beclomethasone solution for 17 children with AH. All patients complained of classic symptoms of chronic nasal obstruction and had an estimated $>90 \%$ adenoid obstruction of the choanae as determined with primary nasal endoscopy. In that study patients were divided randomly into 2 groups; the first group received 4 weeks of intranasal aqueous beclomethasone (336 $\mu \mathrm{g} /$ day) nasal spray treatment followed by 4 weeks of placebo treatment, whereas the second group underwent the same treatments in the reverse order. After the first 8-week period, all children continued topical nasal administration of beclomethasone ( $168 \mu \mathrm{g} /$ day) for 4 months. At the end of the study, significant improvements in adenoid obstruction and symptoms were observed for all patients.

In 2001, Brouillette et al tested the efficacy of another intranasal steroid treatment for OSAS in a randomised, tripleblind, placebo-controlled, parallel-group trial investigating the use of fluticasone propionate nasal spray versus placebo for 25 children affected by OSAS, as demonstrated with polysomnography. Thirteen of 25 patients underwent topical intranasal fluticasone therapy ( $50 \mu \mathrm{g}$ of active drug) with 1 spray per nostril twice daily for the first 7 days and then once daily for an additional 5 weeks. The remaining 12 children received placebo. After treatment, the mixed/obstructive apnoea/hypopnoea index, frequency of haemoglobin desaturation and respiratory movement/arousals decreased more in the fluticasone-treated group compared with the placebo-treated group. Moreover, improvements in symptom scores were observed for $69 \%$ of children who received fluticasone.

In 2003, Criscuoli et al studying 53 children reinforced the conclusions reached by Demain and Goetz. For the first time, they reported on the long-term outcomes of treatment with aqueous nasal beclomethasone for patients with adenotonsillar hypertrophy. Twenty-four patients exhibited improvement after 2 weeks of steroid treatment and an additional 24 weeks of therapy at a lower steroid dose maintained clinical improvement at 52 and 100 weeks for $45.8 \%$ of those patients.
Recently, Cengel and Akyol assessed the efficacy of MF in the treatment of $\mathrm{AH}$ in a prospective, controlled, randomised clinical trial. of 122 patients enrolled 67 received intranasal MF $(100 \mu \mathrm{g} /$ day $)$ therapy for 6 weeks, whereas 55 patients were assigned to the control group. After treatment, a significant decrease of the adenoid mass was observed for $67.2 \%$ of the study group, whereas the clinical situation was unchanged in the control group. It is noteworthy that $8.9 \%$ of MF-treated patients had a positive history and prick-test results for atopy.

Among several commercially available steroid nasal sprays (Beclomethasone dipropionate, budesonide, flunisolide, fluticasone propionate, $\mathrm{MF}$ and triamcinolone acetonide), we chose to test MF for 4 reasons namely, (1) The drug had been reported previously not to cause any adverse tissue changes in the nasal mucosa of patients treated for long periods, (2) It has no effects on growth in children, (3) It has no effects on the hypothalamic-pituitary-adrenal axis ${ }^{11}$ and (4) The systemic availability of the drug after topical administration is lower than that of other steroids. ${ }^{12}$ To date, no standard indications regarding dosage and duration of topical intranasal steroid therapy for the treatment of $\mathrm{AH}$ have been established. Compared with the aforementioned trials, we chose to administer a lower daily steroid dose in each nostril, but for a longer time (first treatment period: 40 days). A single low-dose of intranasally administered steroid was well accepted by parents/legal guardians and children, thereby increasing compliance. Moreover, only 1 complication (Episodic epistaxis) was observed, which demonstrates the safety of intranasal MF administration.

It is critical to highlight that we obtained these successful results for children with only $\mathrm{AH}$. By obstructing the postnasal space, adenoids prevent steroids from acting on the palatine tonsils. In the study by Demain and Goetz, ${ }^{13}$ no evident tonsillar changes were observed for 7 children who showed beside $\mathrm{AH}$ and moderate tonsillar hypertrophy. Because the steroid nasal spray acts especially in the nasal fossa and nasopharynx, we tested the effects of intranasal MF therapy on patients affected exclusively by AH with no tonsillar hypertrophy.

Several mechanisms such as direct lympholytic action, inhibition of inflammation and alteration of adenoid bacterial flora have been suggested to explain how steroids decrease adenoid pad volume and improve symptoms of AH, although none has yet achieved widespread acceptance. Pre- and postintervention oximetric variables were analysed using paired student ' $\mathrm{t}$ ' test. Correlation between variables was considered using Pearson correlation test. Quality of life questionnaire was assessed using Wilcoxon's Signed Rank test. The data were analysed statistically with SPSS version 16 .

\section{Correlation between Grade of Adenotonsillar} Hypertrophy and Nocturnal Oxygen Saturation

The correlation was assessed using Pearson correlation test. The test showed a strong positive correlation between grade of adenoid hypertrophy and ODI ( $\mathrm{r}-0.790 ; \mathrm{p}<0.001)$. This indicates that the size of adenoids and tonsils aids in assessing the severity of sleep disordered breathing and the same may be used to select children for surgical intervention.

All the pulse oximetric parameters improved significantly after the intervention. Paired t-test was used to analyse the data. 
Pre-intervention most of the patients had ODI grade 1015 , while post-intervention majority have ODI grade $<5$. The mean ODI pre-intervention was 15.13 and that postintervention was 3.42. Standard deviation of pre-intervention ODI and post-intervention ODI was 8.40 and 1.93 respectively. The test statistic was 13.687 and p value < 0.001 . Since $\mathrm{p}$ value is $<0.05$, we conclude that ODI have significantly improved post-intervention.

The mean of mean SP02 pre-intervention was 91.081 and that post-intervention was 94.930 . Standard deviation of preintervention mean SPO2 and post-intervention mean SPO2 was 1.908 and 1.363 respectively. The test statistic was 30.098 and $p$ value $<0.001$. Hence, we can say that mean SPO2 significantly improved in the post-intervention period.

The mean minimum SPO2 has significantly improved post-interventional (87.06 against 80.56). Standard deviation of pre-intervention minimum SPO2 and post-intervention minimum SPO2 was 2.666 and 2.492 respectively. The test statistic was -29.255 and $p$ value $<0.001$. This indirectly points towards the previous observations that mometasone furoate nasal spray therapy is effective in the management of children with OSAS due to adenoid hypertrophy.

\section{CONCLUSION}

Total analysis and assumption of the study can be concluded as:

- $\quad$ There is a strong positive correlation between adenoid hypertrophy and Oxygen Desaturation Index (ODI).

- $\quad$ There is a significant improvement in all pulse oximetric parameters (namely oxygen desaturation index, mean SPO2, minimum SPO2) following mometasone furoate therapy.

- There is a significant improvement in the quality of life of children with sleep disordered breathing and chronic adenoid hypertrophy after mometasone furoate therapy.

- Mometasone therapy can be recommended as the medical treatment modality for children with sleep disordered breathing due to adenoid hypertrophy, as it substantially reduced the morbidity.

\section{REFERENCES}

1. Richtsmeier WJ, Shikhani AH. The physiology and immunology of the pharyngeal lymphoid tissue. Otolaryngol Clin North Am 1987;20(2):219-28.
2. Chisholm EJ, Lew-Gor S, Hajioff D, et al. Adenoid size assessment: a comparison of palapation, nasendoscopy and mirror examination. Clinical Otolaryngology 2005; 30(1):39-41.

3. Fujioka M, Young LW, Girdany BR. Radiographic evaluation of adenoid size in children: adenoidalnasopharyngeal ratio. Am J Radiol 1979;133(3):401-4.

4. Brandtzaeg P. Immunology of the tonsils and adenoids: everything the ENT surgeon needs to know. International Journal of Pediatric Otorhinolaryngology 2003;67(Suppl 1):S69-76.

5. Ikinciogullari A, Dogu F, Ikinciogullari A, et al. Is immune system influenced by adenotonsillectomy in children? International Journal of Pediatric Otorhinolaryngology 2002;66(3):251-7.

6. Goh DY, Galster P, Marcus CL. Sleep architecture and respiratory disturbances in children with obstructive sleep apnoea. American Journal of Respiratory and Critical Care Medicine 2000;162(2):682-6.

7. Urschilz MS, Wolff J, Von Einem V, et al. Reference values for nocturnal home pulse oximetry during sleep in primary school children. Chest 2003;123(1):96-101.

8. Brouillette RT, Morielli A, Liemanis A, et al. Nocturnal pulse oxymetry as an abbreviated testing modality for pediatric obstructive sleep apnoea. Pediatrics 2000;105(2):405-12.

9. Sonn H, Rosenfield RM. Evaluation of sleep-disordered breathing in children. Otolaryngology and Head and Neck Surgery 2003;128(3):344-52.

10. Sie KC, Perkins JA, Clarke WR. Acute right heart failure due to adenotonsillar hypertrophy. International Journal of Pediatric Otorhinolaryngology 1997;41(1):53-8.

11. Boner AL. Effects of intranasal corticosteroids on the hypothalamic-pituitary-adrenal axis in children. J Allergy Clin Immunol 2001;108(1 Suppl):S32- 9.

12.12.Szefler SJ. Pharmacokinetics of intranasal corticosteroids. J Allergy Clin Immunol 2001;108 (1Suppl): S26-31.

13. Demain JG, Goetz DW. Pediatric adenoid hypertrophy and nasal airway obstruction: reduction with aqueous nasal beclomethasone. Pediatrics 1995;95(3):355-64. 